\title{
The Impact of Social Media Networks Websites Usage on Students' Academic Performance
}

\author{
Mahmoud Maqableh1, Lama Rajab², Walaa Quteshat', Ra'ed Moh'd Taisir Masa'deh1, \\ Tahani Khatib², Huda Karajeh² \\ ${ }^{1}$ Management Information Systems, Faculty of Business, The University of Jordan, Amman, Jordan \\ ${ }^{2}$ Computer Information Systems, King Abdullah II School for Information Technology, University of Jordan, \\ Amman, Jordan \\ Email: maqableh@ju.edu.jo
}

Received 15 March 2015; Revised 20 August 2015; Accepted 22 September 2015

Copyright (C) 2015 by authors and Scientific Research Publishing Inc.

This work is licensed under the Creative Commons Attribution International License (CC BY). http://creativecommons.org/licenses/by/4.0/

\section{(c) (i) Open Access}

\section{Abstract}

Social Networks Sites (SNSs) are dominating all internet users' generations, especially the students' communities. Consequently, academic institutions are increasingly using SNSs which leads to emerge a crucial question regarding the impact of SNSs on students' academic performance. This research investigates how and to what degree the use of SNSs affects the students' academic performance. The current research's data was conducted by using drop and collect surveys on a large population from the University of Jordan. 366 undergraduate students answered the survey from different faculties at the university. In order to study the impact of SNSs on student's academic performance, the research hypotheses was tested by using descriptive analysis, T-test and ANOVA. Research results showed that there was a significant impact of SNS on the student's academic performance. Also, there was a significant impact of SNS use per week on the student's academic performance, whereas no differences found in the impact of use of SNSs on academic performance due to age, academic achievement, and use per day to most used sites. The findings of this research can be used to suggest future strategies in enhancing student's awareness in efficient time management and better multitasking that can lead to improving study activities and academic achievements.

\section{Keywords}

Social Network Sites, Academic Performance, University Students, T-Test, ANOVA 


\section{Introduction}

Social Network Sites (SNSs) have attracted millions of Internet users, who have integrated these sites in their daily lives routines. Twitter and Facebook are among the most popular social networks where the students spend most of their times [1]-[3]. LinkedIn is an example of Social Network site that is used by many students, instructors and scholars for academic purposes. Social Media Network sites can have a positive or negative impact on students' academic performance. However, time management is the factor that contributed towards negative academic performance besides excessive social media use [1].

According to the US Digital Year report, individuals’ overall time spent online was among four different online contents including portals, social networking, web-based email's market, and entertainment category (TV and music content, video sites and entertainment news); the second largest share of time spent was on SNS with $14.4 \%$ of time spent [4]. University students made up the major proportion of the online networking community. In addition, given the popularity of SNSs, many professors are beginning to use SNSs for enhancing communication with and among students in their classes, class discussions, and teamwork on projects to improve learning outcomes. However, many recent researches pointed out that students' addiction on SNSs can negatively affect student academic performance [1] [5] [6].

Many researchers are studying the effect of rapid and heavy communication technology used by students on their academic performance [5]-[10]. Although many research results pointed to a negative impact of SNSs usage on academic performance [1] [5] [6]; yet, some researchers found a little or no negative effects on students' academic performance if good multitasking is achieved by students [6]. Therefore, students could have better control on SNSs use if they have more self-regulations and enhanced time management skills [11]. A research group suggested that online social networks could possibly be viewed as a helpful educational technology if more academic staff actually knew how to incorporate them into their curricula [5]. They presented a research model that defines the direct and indirect key factors that affect academic performance of students, particularly, the impact of time spent on social media. The model indicates that students' academic performance is a function of attention span, time management skills, student characteristics, academic competence and time spent on online social networks.

This research aims to add a better clarity to this research area by examining the relationship between the use of SNSs and students' academic performance. Hence, the main objective of our study is to investigate whether there is a positive impact of the use of social network website on undergraduate students' academic performance from all faculties in the University of Jordan. The structure of this paper is as follows. Section 2 reviews the literature and related work to the research. Section 3 describes the research methodology. Section 4 presents the data analysis and results. Section 5 gives further discussion of the findings and concludes the paper.

\section{Literature Review}

Internet is being used by an increasing portion of world's population on a regular and daily basis. Technology is being implemented in most fields of our lives such as education, entertainment, and commerce [12] [13]. Many researchers studied the significance of using social network sites (SNSs), and its impact on the academic performance of high school or college students. Some of these studies focused on the effects of factors such as multitasking, time management, student characteristics and personality, study system and strategy, and academic competency [5]-[10]. Moreover, some researchers studied the cultural difference of SNS patterns uses, the attitudes of users toward SNSs, and their perspective of SNS use [14]. In the following subsections we will discuss the significance of SNSs to undergraduate student, the impact of SNSs on academic performance, and the role of multitasking.

\subsection{The Significance of SNSs to Undergraduate Students}

The academic and social importance of SNSs for undergraduate students was pointed out in literature. Michikyan et al., argued that college students need to develop new networks of support; especially for those with new academic experiences such as: first-year students, first generation college students, and immigrant students [3]. These students may use online network sites such as Facebook, Twitter or LinkedIn to develop the support network they need [15]. Furthermore, social media helps in establishing peer-support networks prior to first-year students arriving to campus. 
As for first generation students, whom parents have not attended university or undergraduate school, social media is very important because it offers emotional support and confidence from Facebook friends [14]. First generation lack parental emotional support given that their parents have not experienced successfully graduating from college and are less involved in society and with teachers [16]. The students' confidence of college application process, for instance, was associated with instrumental support from Facebook friends and information obtained from social media [14]. Accordingly, SNSs are used frequently by more students to build new friendship networks in order to be successful in both social and academic domains [17]. SNSs also help in facilitating the art of learning by providing a media to share ideas which allow students to collaborate with others through building their own virtual communities [1]. [14] stated that Facebook as the most popular example of SNSs plays a crucial role in predicting expectations of college success; i.e. having successful Facebook colleagues in college serve a positive example of people from similar backgrounds.

\subsection{The Impact of SNSs on Academic Performance}

Although SNSs is a very helpful tool in students' hands, it was found by many studies that a negative impact of social network sites usage on academic performance could occur [1] [5] [6]. Many students claimed that SNSs usage did not affect their marks, while others admit that SNSs permanent usage can be a distraction, time consuming, and lead to academic procrastination [1] [18]. In [5] research, results pointed to a negative impact of online social media usage on academic performance; therefore, as time spent on social networking sites increases, the academic performance of the students is seen to deteriorate. Nevertheless; (Junco, 2015) studied the impact of college students' academic level and found that Facebook affected Grade Point Averages (GPAs) negatively for freshmen, sophomores, juniors but not for seniors. Seniors spend less time on Facebook, and they are less likely to post status updates comments, chats, posts, videos or photos than others [10].

On the other hand; as SNSs can be accessed from digital device such as a personal computer, a smart phone, a tablet or a laptop; some studies focused on the impact of using such digital devices on students' academic performance since those devices are the main reason for the excessive usage of SNSs. [6], for instance, said that there is a strong negative correlation between the amount of time spent on the computer and the time spent on study; and again they found that people who spend more time on computers spend less time on studying and get less GPAs. [19] explored that Cell Phone use was negatively related to GPA and positively related to anxiety. They found that high frequency cell phone users tended to have lower GPA, higher anxiety, and lower satisfaction with life relative to their peers who used the cell phone less often.

\subsection{The Role of Multitasking}

Although many researchers say that there is a negative impact between Facebook usage and academic performance, some researchers found that the increase in use of social networks did not necessarily decrease the academic performance of the students [1]. They found that most students did not use social media excessively, however there were some exceptions. In fact, the process of managing time between study and social network usage, known also as multitasking, can mitigate the risk of lower GPAs due to Facebook use. Consequently, in order to be successful, students should learn how to balance academic and social demands. In [5], authors even suggested that instructors could use mandatory policies disallowing students to use their phones and computers unless required for course purposes.

Many students think that time management is the factor that contributed towards negative academic performance besides excessive social media use [1]. However, some researchers found that although students feel competent in their ability to use social networks sites for academic purposes, they did not have the desire or willingness to do so [5]. As mentioned before, [10] pointed out that seniors use Facebook less than freshmen and they are better in multitasking, since they have understood what they need to do in order to be successful. Researchers suggested that first year students must learn how to balance academic and social demands effectively in order to be successful. It is important that these new students should do such balancing through building social connections. Generally speaking, students with more self-regulations were more able to control Facebook use [11].

\section{Research Methodology}

The major elements of this research are established based on preceding literature, either theoretically or empiri- 
cally. This section provides the methodology applied in this study. The methodology includes the research theoretical framework, procedural definitions, research hypotheses, research type and scale, research population and sample, besides data collection and analysis procedures. The reliability and validity of the study are also provided. As this research is deductive and quantitative in its nature, one of the important characteristic of deduction is the need to operationalize the variables of the study in a way that facilitate the measurement of facts quantitatively [20]. Indeed, the independent variable of the use of social networks websites and the dependent variable of academic achievements were identified from [1] [5] [6] [10].

\subsection{Research Theoretical Model}

This study used variables that are common in social network literature. By reviewing the literature, it was noticed that there is a need to examine if the use of social networks websites among universities students could impact their academic achievements directly or moderated by other variable. Figure 1 displays the research's proposed model.

[21] defines social network sites as web-based services that allow individuals to construct a public or semipublic profile within a bounded system, articulate a list of other users with whom they share a connection, and view and traverse their list of connections and those made by others within the system. Indeed, the use of social networks websites may be defined as the degree on which users spend time using social network websites and academic as facts. However, we can define academic achievement as student's performance and to which extent he/she obtained the education objectives, goals and outcomes.

\subsection{Research Hypotheses}

In order to test the causal model of the relationship between the uses of social networks websites and academic achievements; the study is hypothesized as follows:

\subsubsection{The Main Research Hypotheses}

H1: There is a statistically significant impact of the use of social networks websites on academic achievements.

H2: There is a significant difference in the impact of the use of social networks websites on academic achievements due to demographic characteristics.

\subsubsection{The Research Sub-Hypotheses}

H2A: There is a significant difference in the impact of the use of social networks websites on academic achievements due to gender.

H2B: There is a significant difference in the impact of social networks websites on academic achievements due to age.

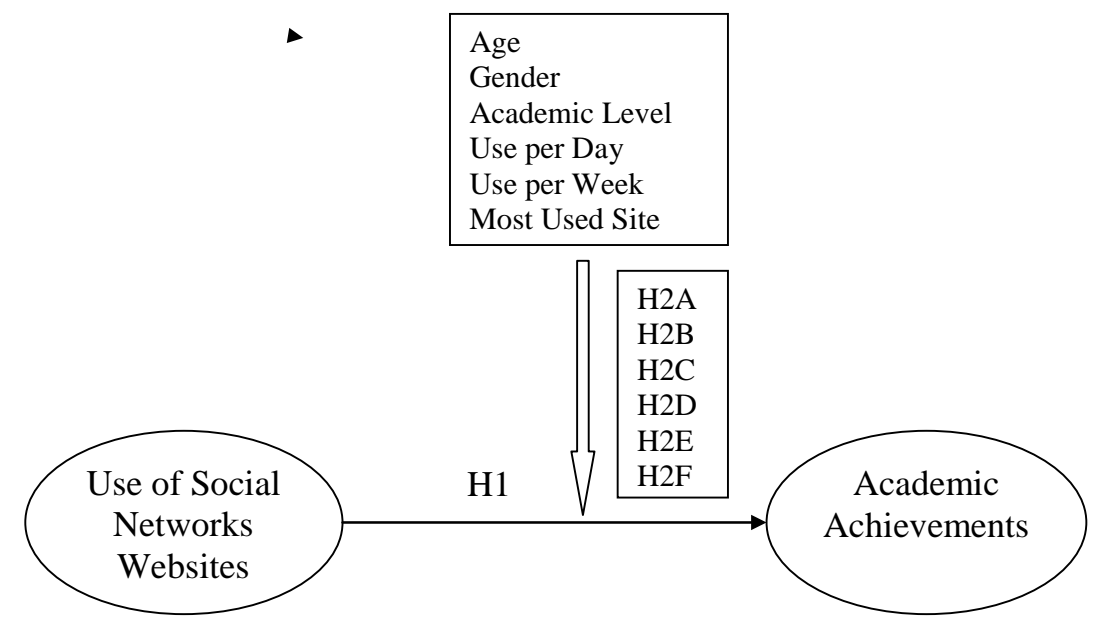

Figure 1. The research model. 
H2C: There is a significant difference in the impact of social networks websites on academic achievements due to academic level.

H2D: There is a significant difference in the impact of social networks websites on academic achievements due to use per day.

H2E: There is a significant difference in the impact of social networks websites on academic achievements due to use per week.

H2F: There is a significant difference in the impact of social networks websites on academic achievements due to most used site.

\subsection{Population and Sample}

Data should be collected from the people that can provide the correct answers to solve the problem [22] and represent the whole people, events or objects the researcher want to study. Therefore, the population of this study consists of bachelor students who studied Social Media Network course as elective course from the University of Jordan located in Jordan, which counts of more than 30,000 students according to the university's registration unit. Indeed, the researchers have chosen bachelor students from all faculties as they are the largest category studying at the University of Jordan. Also, the current research data was conducted by using drop and collect surveys which covers large samples of the population. This technique is less expensive and consumes less time than other methods such as interviews; and covers a wider geographical area. As a result, the researchers used this method of data collection at the University of Jordan. Indeed, by using a drop and collect method to thousands of students, 366 survey questionnaires were returned, which is adequate for statistical analysis, based on [23] [24].

\section{Data Analysis and Results}

Descriptive analysis was used to describe the characteristic of sample and the respondent to the questionnaires. Correlation coefficients were used to determine the relationship between the items for both dependent and independent variables, where the abbreviations of each of the study's variables are as follow: USS: use of social networks websites; and AAS: academic achievements. In addition, a simple linear regression, T-test and ANOVA test were employed to test the hypotheses.

\subsection{Reliability and Validity}

According to [25] it is important to make sure that the instrument developed to measure a particular concept is accurately measuring the variable and is actually measuring the concept that it is supposed to measure in the research. Indeed, reliability analysis is related to the assessment of the degree of consistency between multiple measurements of a variable, whereas validity analysis refers to the degree to which a scale or set of measures accurately represents the construct [26]. The reliability of the instrument was measured by the Cronbach's alpha coefficient. Further, some scholars e.g. [27] suggested that the values of all indicators or dimensional scales should be above the recommended value of 0.60 . However, the Cronbach's alpha for the independent variable (i.e. use of social networks websites) was 0.87 ; while the dependent variable, academic achievements, has a Cronbach's alpha coefficient of 0.86 .

Convergent validity refers to the degree to which items or measures are correlated with each other to measure the same construct. Therefore, higher correlation shows that the scale is assessing its aimed construct. The closer the values are to 1 the more highly correlated the items are, and specifically the individual item reliability is recommended to be greater than 0.50 [27] [28]. Table 1 and Table 2 display the correlations between the independent items, and the dependent items respectively.

It has been noticed from both Table 1 and Table 2 that most of the values were close to 0.5 which indicate a positive correlation between items. This leads to a higher level of convergent validity.

\subsection{Respondents Demographic Profile}

As showed in Table 3, the demographic profile of the respondents for this study revealed that they are typically female, most of them in their second and third year level, about $64 \%$ of them are of ages between 20-less than 23 years old, and using Facebook heavily more over an hour daily and more than 10 hours per week. 
Table 1. Correlations between the independent items.

\begin{tabular}{cccccccc}
\hline USS Items & USS1 & USS2 & USS3 & USS4 & USS5 & USS6 & USS7 \\
\hline USS1 & 1.000 & & & & & \\
USS2 & 0.577 & 1.000 & & & & \\
USS3 & 0.702 & 0.597 & 1.000 & & & \\
USS4 & 0.483 & 0.340 & 0.475 & 1.000 & & \\
USS5 & 0.682 & 0.480 & 0.643 & 0.445 & 1.000 & \\
USS6 & 0.530 & 0.390 & 0.530 & 0.435 & 0.587 & 1.000 \\
\hline
\end{tabular}

Table 2. Correlations between the dependent items.

\begin{tabular}{cccccccc}
\hline AAS Items & AAS1 & AAS2 & AAS3 & AAS4 & AAS5 & AAS6 & AAS7 \\
\hline AAS1 & 1.000 & & & & & & \\
AAS2 & 0.354 & 1.000 & & & & & \\
AAS3 & 0.408 & 0.568 & 1.000 & & & & \\
AAS4 & 0.432 & 0.433 & 0.566 & 1.000 & & & \\
AAS5 & 0.448 & 0.476 & 0.577 & 0.588 & 1.000 & & \\
AAS6 & 0.567 & 0.365 & 0.462 & 0.546 & 0.482 & 1.000 & 1.000 \\
AAS7 & 0.406 & 0.356 & 0.498 & 0.508 & 0.439 & 0.493 & \\
\hline
\end{tabular}

Table 3. Respondents demographic profile based on the researchers' analysis.

\begin{tabular}{|c|c|c|}
\hline $\begin{array}{c}\text { Category } \\
\text { Name of the Company }\end{array}$ & Frequency & Percentage \% \\
\hline \multicolumn{3}{|c|}{ Gender } \\
\hline Male & 107 & 29.2 \\
\hline Female & 259 & 70.9 \\
\hline \multirow[t]{2}{*}{ Total } & 366 & 100 \\
\hline & Age & \\
\hline 17 years-less than 20 & 121 & 33.1 \\
\hline 20 years-less than 23 & 233 & 63.7 \\
\hline 24 years-less than 26 & 9 & 2.5 \\
\hline 27 years and above & 3 & 0.8 \\
\hline \multirow[t]{2}{*}{ Total } & 366 & 100 \\
\hline & Educational Lev & \\
\hline Year 1 & 27 & 7.4 \\
\hline Year 2 & 137 & 37.4 \\
\hline Year 3 & 121 & 33.1 \\
\hline Year 4 & 75 & 20.5 \\
\hline Year 5 and more & 6 & 1.6 \\
\hline Total & 366 & 100 \\
\hline
\end{tabular}




\section{Continued}

\section{Use Per Day}

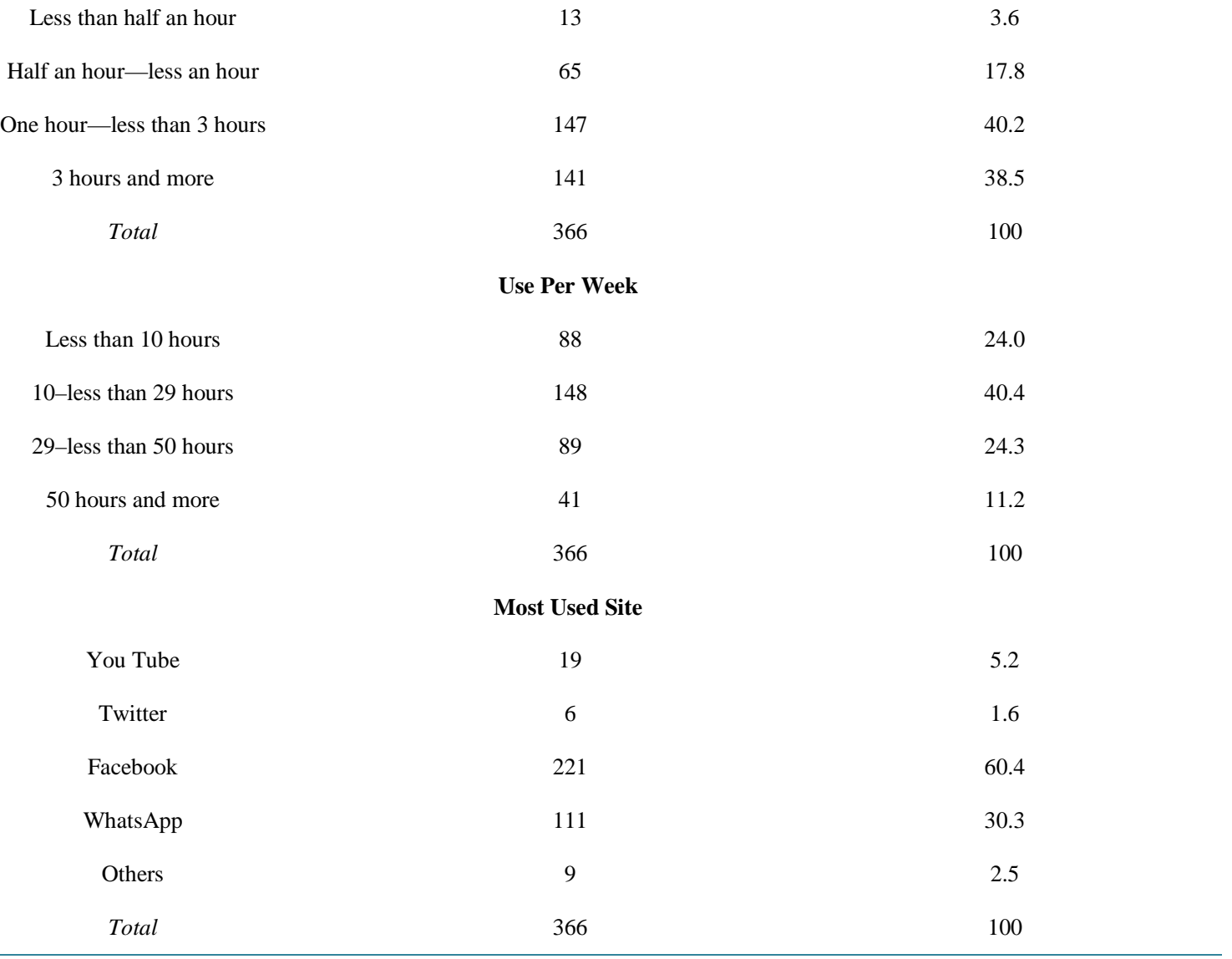

\subsection{Descriptive Analysis}

In order to describe the responses and thus the attitude of the respondents toward each question they were asked in the survey, the mean and the standard deviation were estimated. While the mean shows the central tendency of the data, the standard deviation measures the dispersion which offers an index of the spread or variability in the data [22] [25]. In other words, a small standard deviation for a set of values reveals that these values are clustered closely about the mean or located close to it; a large standard deviation indicates the opposite. Table 4 shows the overall mean and standard deviation of the independent and dependent variables.

As presented in Table 4, data analysis results have shown that the use of social networks websites among bachelor students is applied to a great extent at the University of Jordan in which the mean score is 3.7233. This serves as an indicator on the importance of the use of social networks websites and the essential role that they play in enhancing the students' academic achievements. Furthermore, data analysis results have revealed that academic achievements itself is applied to a great extent at the University of Jordan in which the mean score is 3.7459. This high level of presentation denotes a positive attitude regarding students' academic achievements. This sturdily advocates that University of Jordan is currently engaging in information technology and mobile application activities with their students.

\subsubsection{Independent Variable}

Table 5 demonstrates the mean scores for the use of social networks websites.

\subsubsection{Dependent Variable}

Table 6 demonstrates the mean scores for academic achievements items. 
Table 4. Mean and standard deviation of the study’s variables.

\begin{tabular}{cccc}
\hline Type of Variable & Variables & Mean & Std. Deviation \\
\hline Independent Variable & Use of social networks websites & 3.7233 & 0.70079 \\
Dependent Variable & Academic achievements & 3.7459 & 0.68193 \\
\hline
\end{tabular}

Table 5. Mean and standard deviation for the use of social networks websites.

\begin{tabular}{|c|c|c|}
\hline Use of social networks websites & Mean & Std. Dev \\
\hline Social networking is useful to me as a student. & 3.79 & 0.956 \\
\hline Social networking sites have a positive impact on my Academic Achievement. & 3.31 & 1.108 \\
\hline Social networks help me to achieve my academic goals. & 3.65 & 0.958 \\
\hline $\begin{array}{l}\text { The use of social networks help to improve my contact with my colleagues } \\
\text { and teachers as well as my performances academic. }\end{array}$ & 3.98 & 0.848 \\
\hline $\begin{array}{l}\text { Skills and knowledge obtained during studying Social Networks Course } \\
\text { are very important to my performance and academic achievement. }\end{array}$ & 3.84 & 0.918 \\
\hline I know the most important concepts and facts relating to social netlworks communications have improved. & 3.83 & 0.863 \\
\hline The study of topics related to social networking has a positive impact on my life in the future. & 3.68 & 0.850 \\
\hline
\end{tabular}

Table 6. Mean and standard deviation for academic achievements.

\begin{tabular}{|c|c|c|}
\hline Use of social networks websites & Mean & Std. Dev. \\
\hline I deal with social networking sites are faster. & 3.97 & 0.980 \\
\hline Currently I use social networking sites more than before and frequently. & 3.76 & 0.935 \\
\hline My performance has improved in the use of social networking sites better than before. & 3.72 & 0.877 \\
\hline Recently, I was introduced to the new features of the social networking sites. & 3.74 & 0.893 \\
\hline Recently, I have developed my use of various social networking sites. & 3.62 & 0.897 \\
\hline Recently, I have developed my skills and knowledge in the use of social networking sites. & 3.80 & 0.891 \\
\hline Recently, I learned how to think and analysis of topics on the subject of social networking critically. & 3.62 & 0.977 \\
\hline
\end{tabular}

\subsubsection{The Moderating Variables}

The demographic characteristics of student are the moderating variables in this study. These variables are used in order to identify if there are different patterns between academic achievements among respondents. The demographic characteristics in this study include gender, age, academic level, use per day, use per week, and most used site.

\subsection{Hypothesis Testing Results}

The purpose of this study was to test the impact of the use of social networks websites on academic achievements. Thus, in order to test the hypotheses developed for this study, a simple linear regression technique was used. Further, the level of significance ( $\alpha$-level) was chosen to be 0.05 and the probability value (p-value) obtained from the statistical hypotheses test is considered to be the decision rule for rejecting the null hypotheses [29]. If the p-value is less than or equal to $\alpha$-level, the null hypothesis will be rejected and the alternative hypothesis will be supported. However, if the p-value is greater than the $\alpha$-level, the null hypothesis cannot be rejected and the alternative hypothesis will not be supported.

\subsubsection{Hypothesis 1}

H1: There is a statistically significant impact of the use of social networks websites on academic achievements. The results of testing of the main hypothesis are demonstrated in Tables 7-9. 
Table 7. Study model summary.

\begin{tabular}{ccccc}
\hline Model & $\mathbf{R}$ & R Square & Adjusted R Square & Std. Error of the Estimate \\
\hline 1 & 0.839 a & 0.703 & 0.702 & 0.37196 \\
\hline
\end{tabular}

a: Predictors: (Constant), USS.

Table 8. Analysis of variance for the study model (b).

\begin{tabular}{ccccccc}
\hline Model & Sum of Squares & Df & Mean Square & F & Sig. & Result \\
\hline Regression & 119.376 & 1 & 119.376 & 862.852 & $0.000 \mathrm{a}$ & Accept the hypothesis \\
Residual & 50.360 & 364 & 0.138 & & & \\
Total & 169.736 & 365 & & & & \\
\hline
\end{tabular}

a: Predictors: (Constant), UUS; b: Dependent Variable: AAS.

Table 9. Coefficient of predictors (a).

\begin{tabular}{ccccccc}
\hline \multirow{2}{*}{ Model } & \multicolumn{2}{c}{ Unstandardized Coefficients } & & \multirow{2}{*}{ T } & Sig. & Result of Hypothesis Testing \\
\cline { 2 - 3 } & B & Std. Error & & & \\
\hline (Constant) & 0.707 & 0.105 & 6.722 & 0.000 & Accept the hypothesis \\
\hline USS & 0.816 & 0.028 & 29.374 & 0.000 & . \\
\hline
\end{tabular}

Dependent variable: AAS.

The multiple correlation coefficient $\mathrm{R}=0.839$ shows that there is a positive correlation between the use of social networks websites on academic achievements. This means that the independent variable and the dependent variable change in the same direction. The multiple correlation coefficient is a gauge of how well the model predicts the observed data. The value of R2 $=0.703$ indicates the amount of variations in academic achievements that is accounted by the fitted model. This is to say that $70.3 \%$ of the variability of academic achievements has been explained by the variable of the use of social networks websites. Also, the higher the use of social networks websites, the higher the applicability of academic achievements itself. In order to generalize the results obtained from the respondents to the whole population, adjusted R2 was calculated. Indeed, adjusted R2 was equals $70.2 \%$, indicating a high degree of generalizability of the model. Table 8 showed the Analysis of variance (ANOVA) analysis to test the main null hypothesis. Indeed, F-ratio for the data was 862.852 which is significant at $\mathrm{p}<0.05$ (sig $=0.000$ ). Therefore, there was a statistically significant impact of the use of social networks websites on academic achievements, and thus reject the null hypothesis and accept the alternative hypothesis. Moreover, the equation of the single linear regression takes this formula:

$$
Y=\beta_{0}+\beta_{1} X_{1}+\varepsilon i
$$

By testing the impact of the predictor included in the model (i.e. using the value of $\beta$ and $\alpha$ significance level) on the dependent variable, we can infer the acceptability of the hypothesis. The $\beta$ indicates the individual contribution of the predictor to the model if the predictor is held constant. Table 9 shows that for the use of social networks websites; the value of $\beta$ was 0.816 ; and considered to be high. In addition, t-value was above 1.96. Indeed, we can infer from the values of $\beta$ and t-value that the use of social networks websites did have a statistically significant impact on students' academic achievements at the University of Jordan.

\subsubsection{Hypothesis 2}

Hypotheses H2A, H2B, H2C, H2D, H2E and H2F argued that there is a significant difference in the impact of the use of social networks websites on academic achievements due to gender, age, academic level, use per day, use per week, and most used site respectively. Independent Samples T-test was employed in order to investigate if there any significant differences in the impact of the use of social networks websites on academic achievements that can be attributed to gender. Also, ANOVA test was employed to examine if there any significant differences in the impact the use of social networks websites on academic achievements that can be attributed to age, academic level, use per day, use per week, and most used site. 
Results of T-test, shown in Table 10, indicated that there is no significant difference in the impact of the use of social networks websites on academic achievements that can be attributed to gender. On the other hand, results of ANOVA test, shown in Table 11, Table 12, Table 15 and Table 16, indicated that there is no significant difference in the impact of the use of social networks websites on academic achievements in favor of age, academic level, use per week, and most used site; whereas Table 13 indicated that there is a significant difference in the impact of the use of social networks websites on academic achievements in favor of use per day. Therefore, Table 14 provided the statistical significance of the differences between each pair of groups for use per day. As noticed in Table 14, the four groups (i.e. less than half an hour, Half an hour-less an hour, One hour-less than 3 hours, 3 hours and more) were statistically different from one another.

\section{Discussion and Conclusions}

The primary motivation of this research is to test the relationship between the use of social networks websites and the student's academic performance. The population of this study consists of undergraduates students from all faculties of the University of Jordan. After analyzing the respondents demographic profile, it revealed that they are typically females and most of them in the second and third year level (sophomores and juniors), with ages between 20 - 23 years old. Results also show that they are using Facebook heavily given that $38.5 \%$ of students are spending three hours daily, and about $40 \%$ of them are spending more than 10 hours per week.

The proposed model has two main hypotheses (H1 and H2). The fist hypothesis claims that there is a direct and significant impact of the use of social networks and the student's academic performance. On the other hand, the second hypothesis with its sub hypotheses (H2A, H2B, H2C, H2D, H2E, and H2F) claims that there is a difference in the impact of use of social networks websites due to demographic characteristics (moderate variables: age, gender, academic level, use per day, use per week, and the most used site). Before testing the proposed hy-

Table 10. T-test of the use of social networks websites on academic achievements attributed to gender.

\begin{tabular}{|c|c|c|c|c|c|c|c|c|c|}
\hline \multirow{2}{*}{ Variables } & \multicolumn{3}{|c|}{ Male } & \multicolumn{3}{|c|}{ Female } & \multirow{2}{*}{$\mathbf{T}$} & \multirow{2}{*}{ df } & \multirow{2}{*}{ Sig. } \\
\hline & $\mathbf{N}$ & Mean & Std. Dev. & $\mathbf{N}$ & Mean & Std. Dev. & & & \\
\hline Academic achievements & 107 & 3.6182 & 0.88972 & 259 & 3.7987 & 0.56842 & 1.911 & 143.090 & 0.066 \\
\hline
\end{tabular}

Table 11. ANOVA Analysis of the use of social networks websites on academic achievements attributed to age.

\begin{tabular}{lccccc}
\hline \multicolumn{1}{c}{ Variables } & & Sum of Squares & Df & Mean Square & F \\
\hline & Between Groups & 0.968 & 3 & 0.323 \\
Academic achievements & Within Groups & 168.768 & 362 & 0.692 \\
& Total & 169.736 & 365 & \\
\hline
\end{tabular}

Table 12. ANOVA Analysis of the use of social networks websites on academic achievements attributed to academic level.

\begin{tabular}{cccccc}
\hline \multicolumn{1}{c}{ Variables } & & Sum of Squares & Df & Mean Square & F \\
\hline & Between Groups & 0.894 & 4 & 0.223 & 0.478 \\
Academic achievements & Within Groups & 168.842 & 361 & 0.468 \\
& Total & 169.736 & 365 & \\
\hline
\end{tabular}

Table 13. ANOVA Analysis of the use of social networks websites on academic achievements attributed to use per day.

\begin{tabular}{cccccc}
\hline Variables & & Sum of Squares & Df & Mean Square & F \\
\hline & Between Groups & 9.485 & 3 & 3.162 & 0.000 \\
Academic achievements & Within Groups & 160.252 & 362 & 0.443 \\
& Total & 169.736 & 365 & \\
\hline
\end{tabular}


Table 14. Multiple comparisons analysis of the use of social networks websites on academic achievements attributed to use per day.

\begin{tabular}{|c|c|c|c|c|c|c|}
\hline \multirow{2}{*}{$\begin{array}{c}\text { (I) } \\
\text { use per day }\end{array}$} & \multirow{2}{*}{$\begin{array}{c}\text { (J) } \\
\text { use per day }\end{array}$} & \multirow{2}{*}{ Mean Difference (I-J) } & \multirow{2}{*}{ Std. Error } & \multirow{2}{*}{ Sig. } & \multicolumn{2}{|c|}{ 95\% Confidence Interval } \\
\hline & & & & & Lower Bound & Upper Bound \\
\hline \multirow{3}{*}{$\begin{array}{l}\text { Less than } \\
\text { half an hour }\end{array}$} & Half an hour-less an hour & $-0.72308^{*}$ & 0.202150 & 0.002 & -1.2448 & -0.2013 \\
\hline & One hour-less than 3 hours & $-0.75181^{*}$ & 0.19252 & 0.0010 & -1.2487 & -0.2549 \\
\hline & 3 hours and more & $-0.87608^{*}$ & 0.19285 & 0.0000 & -1.3738 & -0.3783 \\
\hline \multirow{3}{*}{$\begin{array}{l}\text { Half an } \\
\text { hour-less } \\
\text { an hour }\end{array}$} & Less than half an hour & $0.72308^{*}$ & 0.20215 & 0.002 & 0.2013 & 1.2448 \\
\hline & One hour-less than 3 hours & -0.02874 & 0.09911 & 0.991 & -0.2845 & 0.22710 \\
\hline & 3 hours and more & -0.15300 & 0.09975 & 0.418 & -0.4105 & 0.1045 \\
\hline \multirow{3}{*}{$\begin{array}{l}\text { One hour-less } \\
\text { than } 3 \text { hours }\end{array}$} & Less than half an hour & $0.75181^{*}$ & 0.19252 & 0.001 & 0.2549 & 1.2487 \\
\hline & Half an hour-less an hour & 0.02874 & 0.09911 & 0.991 & -0.2271 & 0.2845 \\
\hline & 3 hours and more & -0.12427 & 0.07843 & 0.389 & -0.3267 & .07820 \\
\hline \multirow{3}{*}{$\begin{array}{l}3 \text { hours } \\
\text { and more }\end{array}$} & Less than half an hour & $0.87608^{*}$ & 0.19285 & 0.000 & 0.3783 & 1.3738 \\
\hline & Half an hour-less an hour & 0.153000 & 0.09975 & 0.418 & -0.1045 & 0.4105 \\
\hline & One hour-less than 3 hours & 0.12427 & 0.07843 & 0.389 & -0.0782 & 0.3267 \\
\hline
\end{tabular}

*The mean difference is significant at the 0.05 level.

potheses, it was important to measure the consistency between the measured variables and how accurately they represent the proposed construct. For this purpose, the reliability and the convergent validity for both independent variable (use of social networks website) and dependent variable (academic achievement) were approved. Cronbach's alpha coefficient and the correlation between the variables showed satisfactory results.

In order to test the hypotheses, a simple linear regression technique, T-test and ANOVA, were used. The main hypothesis $\mathrm{H} 1$ was analyzed. The results shown in Tables 7-9 indicated that there was a statistically significance impact of the use of social networks websites on academic achievement. Since the correlation showed that the use of social networks and the academic performance variables were highly correlated and changed in the same direction. Hypotheses H2A, H2B, H2C, H2D, H2E, and H2F stated that there were significant differences in the impact of the use of social networks websites on academic achievements due to gender, age, academic level, use per day, use per week and most used site, respectively. T-test was used to test hypotheses H2A which stated that there was no significant difference in the impact of the use of social networks on academic achievement due to gender. The p-value (significance level) was 0.066 which is greater than the $\alpha$ level 0.05 as explained in the results section so this means that we fail to reject the hypothesis as was shown in Table 10.

The remaining hypotheses (H2B, H2C, H2D, H2E, and H2F) were tested by using the ANOVA test and the significance level for them all is greater than 0.05 which means that there is no significance difference in the impact of use of social networks websites on academic achievements due to age, academic achievement, use per week and to most used sites as shown in Tables 10-12, Table 15 and Table 16 in the previous section. But surprisingly the significance level of the use per day indicated that there was a significance difference in the impact of use of social networks on the academic achievement due to use per day. Further tests was made between groups: (less than half an hour, half an hour-less and hour, one hour-less than 3 hours, 3 hours and more) as shown in Table 14, the results revealed that the higher the number of hours had more effect on the academic achievement which is reasonable because that number of hours per day is limited and the chance for multitasking is also limited which will finally affect the academic performance.

When comparing the use per day with the use per week results, one can obviously notice that there was no impact of using social networks websites per week on the academic achievement. We think that this result can be justified by saying that the time might be utilized more efficiently during the weekend. Students have more free hours during the weekend day, so multitasking can be achieved more and students will compensate the time they wasted during the week and will focus on efficient studying. We recommend that future researches should 
Table 15. ANOVA Analysis of the use of social networks websites on academic achievements attributed to use per week.

\begin{tabular}{ccccccc}
\hline Variables & & Sum of Squares & df & Mean Square & F & Sig. \\
\hline & Between Groups & 2.511 & 3 & 0.837 & 1.812 & 0.145 \\
Academic achievements & Within Groups & 167.226 & 362 & 0.462 & & \\
& Total & 169.736 & 365 & & \\
\hline
\end{tabular}

Table 16. ANOVA Analysis of the use of social networks websites on academic achievements attributed to most used site.

\begin{tabular}{ccccccc}
\hline \multicolumn{1}{c}{ Variables } & & Sum of Squares & Df & Mean Square & F & Sig. \\
\hline & Between Groups & 1.762 & 4 & 0.441 & 0.947 & 0.437 \\
Academic achievements & Within Groups & 167.974 & 361 & 0.465 & & \\
& Total & 169.736 & 365 & & \\
\hline
\end{tabular}

consider the negative impact of excessive usage of social networks on students' performance and achievements. Consequently more studies should focus on the importance of faculties' workshops and seminars that can be useful in training student to manage the use of social networks more efficiently.

\section{References}

[1] Karpinski, A.C., Kirschner, P.A. Ozer, I., Mellott, J.A. and Ochwo, P. (2013) An Exploration of Social Networking Site Use, Multitasking, and Academic Performance among United States and European University Students. Computers in Human Behavior, 29, 1182-1192. http://dx.doi.org/10.1016/j.chb.2012.10.011

[2] Alwagait, E., Shahzad, B. and Alim, S. (2014) Impact of Social Media Usage on Students Academic Performance in Saudi Arabia. Computers in Human Behavior, 51, 1092-1097.

[3] Michikyan, M., Subrahmanyam, K. and Dennis, J. (2015) Facebook Use and Academic Performance among College Students: A Mixed-Methods Study with a Multi-Ethnic Sample. Computers in Human Behavior, 45, 265-272. http://dx.doi.org/10.1016/j.chb.2014.12.033

[4] ComScore.com (2012) Internet Website. ComScore. http://www.comscore.com/Insights/Presentations-and-hitepapers/2012/2012-US-Digital-Future-in-Focus

[5] Paul, J.A., Baker, H.M. and Cochran, J.D. (2012) Effect of Online Social Networking on Student Academic Performance. Computers in Human Behavior, 28, 2117-2127. http://dx.doi.org/10.1016/j.chb.2012.06.016

[6] Wentworth, D.K. and Middleton, J.H. (2014) Technology Use and Academic Performance. Computers \& Education, 78, 306-311. http://dx.doi.org/10.1016/j.compedu.2014.06.012

[7] Lomi, A., Snijders, T.A.B. Steglich, C.E.G. and Torló, V.J. (2011) Why Are Some More Peer than Others? Evidence from a Longitudinal Study of Social Networks and Individual Academic Performance. Social Science Research, 40, 1506-1520. http://dx.doi.org/10.1016/j.ssresearch.2011.06.010

[8] Mehmood, S. (2013) The Effects of Social Networking Sites on the Academic Performance of Students in College of Applied Sciences, Nizwa, Oman. International Journal of Arts and Commerce, 2, 111-125.

[9] Ellore, S.B., Niranjan, S. and Brown, U.J. (2014) The Influence of Internet Usage on Academic Performance and Face-to-Face Communication. Journal of Psychology and Behavioral Science, 2, 163-186.

[10] Junco, R. (2015) Student Class Standing, Facebook Use, and Academic Performance. Journal of Applied Developmental Psychology, 36, 18-29. http://dx.doi.org/10.1016/j.appdev.2014.11.001

[11] Rouis, S., Limayem, M. and Salehi-Sangari, E. (2011) Impact of Facebook Usage on Students’ Academic Achievement: Role of Self-Regulation and Trust. Electronic Journal of Research in Educational Psychology, 9, 961-994.

[12] Karajeh, H., Maqableh, M. and Masa'deh, R. (2014) A Review on Stereoscopic 3D: Home Entertainment for the Twenty First Century. Vol. 5, Springer, New York, 1-9.

[13] Maqableh, M. (2012) Analysis and Design Security Primitives Based on Chaotic Systems for E-Commerce. Durham University, Durham.

[14] Rienties, B. and Tempelaar, D. (2013) The role of Cultural Dimensions of International and Dutch Students on Academic and Social Integration and Academic Performance in the Netherlands. International Journal of Intercultural Relations, 37, 188-201. http://dx.doi.org/10.1016/j.ijintrel.2012.11.004 
[15] Deandrea, D.C., Ellison, N.B., Larose, R., Steinfield, C. and Fiore, A. (2012) Serious Social Media: On the Use of Social Media for Improving Students’ Adjustment to College. Internet and Higher Education, 15, 15-23. http://dx.doi.org/10.1016/j.iheduc.2011.05.009

[16] Wohn, D.Y., Ellison, N.B., Khan, M.L., Fewins-Bliss, R. and Gray, R. (2013) The Role of Social Media in Shaping First-Generation High School Students’ College Aspirations: A Social Capital Lens. Computers \& Education, 63, 424436. http://dx.doi.org/10.1016/j.compedu.2013.01.004

[17] Ramírez Ortiz, M.G., Caballero Hoyos, J.R. and Ramírez López, M.G. (2004) The Social Networks of Academic Performance in a Student Context of Poverty in Mexico. Social Networks, 26, 175-188. http://dx.doi.org/10.1016/j.socnet.2004.01.010

[18] Ozer, I., Karpinski, A.C. and Kirschner, P.A. (2013) A Cross-Cultural Qualitative Examination of Social-Networking Sites and Academic Performance. Procedia-Social and Behavioral Sciences, 112, 873-881.

[19] Lepp, A., Barkley, J.E. and Karpinski, A.C. (2014) The Relationship between Cell Phone Use, Academic Performance, Anxiety, and Satisfaction with Life in College Students. Computers in Human Behavior, 31, 343-350. http://dx.doi.org/10.1016/j.chb.2013.10.049

[20] Saunders, M., Lewis, P. and Thornhill, A. (2007) Research Methods for Business Students. 4th Edition, Financial Times Prentice Hall, Edinburgh Gate, Harlow.

[21] Boyd, D.M. and Ellison, N.B. (2007) Social Network Sites: Definition, History, and Scholarship. Journal of Computer-Mediated Communication, 13, 210-230. http://dx.doi.org/10.1111/j.1083-6101.2007.00393.x

[22] Sekaran, U. (2003) Research Methods for Business: A Skill-Building Approach. 4th Edition, John Wiley and Sons, Hoboken.

[23] Krejcie, R.V. and Morgan, D.W. (1970) Determining Sample Size for Research Activities. Educational and Psychological Measurement, 30, 607-610.

[24] Pallant, J. (2005) SPSS Survival Guide-A Step by Step Guide to Data Analysis Using SPSS for Windows. Open University Press, Chicago.

[25] Sekaran, U. and Roger, B. (2013) Research Methods for Business: A Skill-Building Approach. 6th Edition, John Wiley and Sons, Hoboken.

[26] Hair, J., Anderson, R., Tatham, R. and Black, W. (1998) Multivariate Data Analysis. Vol. 259, 5th Edition, Prentice-Hall International Inc., Upper Saddle River.

[27] Bagozzi, R. and Yi, Y. (1988) On the Evaluation of Structural Equation Models. Journal of the Academy of Marketing Science, 16, 74-94. http://dx.doi.org/10.1007/BF02723327

[28] Fornell, C. and Larcker, D.F. (1981) Evaluating Structural Equation Models with Unobservable Variables and Measurement Error. Journal of Marketing Research, 18, 39-50.

[29] John, W.C. (2009) Research Design: Qualitative, Quantitative, and Mixed Methods Approaches. 3th Edition, Sage Publications, Thousand Oaks. 